\title{
Erratum to: Mutational dynamics and phylogenetic utility of noncoding chloroplast DNA
}

\author{
Thomas Borsch • Dietmar Quandt
}

Published online: 10 November 2009

(c) Springer-Verlag 2009

Erratum to: Plant Syst Evol (2009) 282:169-199

DOI 10.1007/s00606-009-0210-8

In the original published version of this article, in Fig. 1 and in the figure legend, the colors of intron and intergenic spacer are exchanged. The correct classification is:

yellow $=$ intergenic spacer

red $=$ intron

The online version of the original article can be found under doi:10.1007/s00606-009-0210-8.

\section{T. Borsch ( $\square)$}

Botanischer Garten und Botanisches Museum Berlin-Dahlem und Institut für Biologie/Botanik, Freie Universität Berlin,

Königin-Luise Str. 6-8, 14195 Berlin, Germany

e-mail: t.borsch@bgbm.org

D. Quandt ( $\square)$

Nees-Institut für Biodiversität der Pflanzen, Universität Bonn, Meckenheimer Allee 170, 53115 Bonn, Germany

e-mail: quandt@uni-bonn.de 